\title{
Holocene paleo-sea level changes along the coast of Rio de Janeiro, southern Brazil: Comment on Castro et al. (2014)
}

\section{RODOLFO J. ANGULO ${ }^{1}$, PAULO C.F. GIANNINI ${ }^{2}$, MARIA CRISTINA DE SOUZA ${ }^{1}$ and GUILHERME C. LESSA ${ }^{3}$}

${ }^{1}$ Centro Politécnico, Departamento de Geologia, UFPR, Laboratório de Estudos Costeiros/Lecost, Av.

Cel. Francisco H. dos Santos, 210, Jardim das Américas, 81531-970 Curitiba, PR, Brazil

${ }^{2}$ Instituto de Geociências, USP, Rua do Lago, 562, Cidade Universitária, 05508-080 São Paulo, SP, Brazil

${ }^{3}$ Grupo de Oceanografia Tropical/GOAT, UFBA, Travessa Barão de Jeremoabo, s/n, Campus

Universitário de Ondina, LFNA, sala 02, 40170-280 Salvador, BA, Brazil

Manuscript received on December 15, 2014; accepted for publication on March 16, 2015

\begin{abstract}
The present work discusses and reinterprets paleo-sea level indicators used to build Holocene sea-level curve for the coast of Rio de Janeiro at former works. We conclude that: (a) the paleo-sea levels inferred by vermetid remains show that sea-level has fallen over the past 4400 years, at least; (b) the paleo-sea level inferred by the beachrock facies and dated shells of Jaconé shows that sea-level was near the present elevation between 8198 and 5786 years before present; and (c) several shells from other beachrocks were deposited probably thousands of years after the specimens died and consequently do not allow precise reconstructions of paleo-sea levels. These conclusions differ from the conclusions of the original paper.
\end{abstract}

Key words: Beachrock, paleo-sea level reinterpretation, sea-level curve, vermetids, Tetraclita stalactifera.

\section{INTRODUCTION}

Investigations of relative sea-level changes at local and regional scales are important to distinguish the impact of land tectonics and isostasy from those of eustatic sea level changes. This works aims to comment and provide alternative interpretations to the data used by Castro et al. (2014) to discuss the behavior of the paleo-sea level at Rio de Janeiro coast during the Mid to Late Holocene.

\section{RESULTS AND DISCUSSION}

Castro et al. (2014) paper presents new relevant information to aid with Holocene relative sea-

Correspondence to: Rodolfo José Angulo

E-mail: fitoangulo@gmail.com level (RSL) reconstructions along the coast of Rio de Janeiro. The data set is extensive (29 listed indicators, out of which 14 were used in the sea level curve) and from different sources. However, there are several problems that compromise the authors' interpretations and final conclusions.

The first concerns, and perhaps the most compromising, is related to the paleo-sea level reconstruction. The authors mistake the altitude of the indicators as the paleo-sea level. As a result, their final paleo-sea level curve is not a relative curve but a curve showing the altitude of the paleosea level indicators (vermetids and beachrock shells).

Castro et al. (2014) postulate that one of the greatest challenges in generating an RSL curve is 
defining the altitude of the biological and geological samples in reference to "zero" (i.e., the current mean sea-level). It has been well known since the seminal papers of Hartt (1870) and Branner $(1902,1904)$ that paleo-sea level reconstructions must consider the vertical distance between a given indicator and its present homologous one. For example Branner $(1902,1904)$ compares the upper limit of former urchin holes with the upper limit of living urchins. As this distance is around $2 \mathrm{~m}$ the author correctly concludes that the older urchin holes indicate a paleo-sea level $2 \mathrm{~m}$ higher than the present one. Hence, there is no need to determine the present mean-sea level. This procedure was largely accepted and is described in several manuals on sea-level reconstructions (e.g. Martin et al. 1982, Van de Plassche 1986, Pirazzoli 1996).

Castro et al. (2014) also postulate that several investigations conducted on the South American coasts regarding relative sea-level variations have not clearly or precisely defined the reference level of the samples used in the vertical plane. This is true because it is not necessary. The authors stress that the absence of this information yields potential inaccuracies regarding the height of the marine paleo-levels of the proposed curves. That, on the other hand, is incorrect because the inaccuracies in defining paleo-sea levels are related to the intrinsic characteristics of the given indicator, its vertical spread and the uncertainty related to where, within this spread, the remains are from. It is not related to the accuracy of determining the present meansea level. On the same line the authors also stress that the field method applied for estimating the elevations of the samples (GPS trackers) has a very small margin of error and therefore suggest that the method employed in this study would need to be applied to other parts of the Brazilian coastline. We emphasize that this procedure is not necessary, and that efforts must concentrate on the determination of the vertical distance between the paleo-sea level indicators and their living homologous one.
Moreover, the error inherent to the paleo-sea level indicator is tens to hundreds of times larger than the measurement error associated with GPS trackers.

Other worth-mentioning confusions in the paper are:

(1) The authors assertion that their results confirm other data already obtained elsewhere along the Atlantic coast of South America. This is not possible because along the Atlantic coast of South America there are divergent data (e.g. Martin et al. 2003, Angulo et al. 2006), including a former Castro et al. (2012) paper where it is postulated that at 13,130 calibrated years before present (cal a BP) sea-level at Cabo Frio was $1.5 \mathrm{~m}$ above present sealevel. Furthermore, it is remarkable that those two comprehensive papers about Holocene sea-level changes along the Brazilian coast (Martin et al. 2003, Angulo et al. 2006) have not been referenced. In addition, several paleo-sea level reconstructions from the state of Rio de Janeiro were not even mentioned, including those from Cabo Frio region published in former works (Laborel 1969, Delibrias and Laborel 1969, Martin et al. 1979, 1979/80, 1983, 1984, 1996, 1997, Martin and Suguio 1978, 1989, Maia et al. 1984, Table I) and used by Angulo et al. (2006) to build the Brazilian sea-level envelope from Pernambuco to Paraná (Fig. 1)

(2) The authors inform that the vermetid used as a paleo-sea level indicator corresponds to Laguncularia racemosa. This is a mangrove, not vermetid, species. Probably the vermetid found at Cabo Frio corresponds to Petaloconchus (Macorphragma) varians, the most common vermetid species along the Brazilian coast.

(3) The authors inform that eight percussion drills were performed perpendicular to the coastline within the study area, but no data or interpretation of those cores are presented in the paper.

(4) The authors inform that in total, 29 (or 22) samples were radiocarbon dated for conventional method but we can only identify 14 dated samples in the curve. Besides, there is no clear indication 
TABLE I

Paleo-sea levels inferred from vermetids and barnacles remains from the coast of Rio de Janeiro.

\begin{tabular}{|c|c|c|c|c|c|c|c|c|}
\hline Place & SL & WL & $\mathrm{N}$ & ${ }^{14} \mathrm{C}$ a BP & cal a BP & $\mathrm{R}$ & $\mathrm{H}(\mathrm{m})$ & PSL (m) \\
\hline Ilha Grande ${ }^{(1,2)}$ & $23^{\circ} 08^{\prime}$ & $44^{\circ} 10$ & $\mathrm{v}$ & $380 \pm 90$ & $0^{(9)}$ & Gif-1061 & - & $0.5 \pm 1.0^{(9)}$ \\
\hline Ilha Grande ${ }^{(1,2)}$ & $23^{\circ} 00,0^{\prime}$ & $45^{\circ} 00,0^{\prime}$ & $\mathrm{v}$ & $1670 \pm 100$ & $1401-983^{(9)}$ & Gif 1060 & - & $1.5 \pm 1.0^{(9)}$ \\
\hline Ilha Grande ${ }^{(1,2)}$ & $23^{\circ} 08^{\prime}$ & $44^{\circ} 10^{\prime}$ & $\mathrm{v}$ & $3420 \pm 110$ & $3536-2970^{(9)}$ & Gif-1059 & - & $3.0 \pm 1.0^{(9)}$ \\
\hline Cabo Frio ${ }^{(1,2)}$ & $22^{\circ} 54,3^{\prime}$ & $42^{\circ} 00,0^{\prime}$ & $\mathrm{v}$ & $2400 \pm 95$ & $2283-1814^{(9)}$ & Gif-1935 & - & $2.0 \pm 1.0^{(9)}$ \\
\hline Cabo Frio ${ }^{(1,2)}$ & $22^{\circ} 54,3^{\prime}$ & $42^{\circ} 00,0^{\prime}$ & $\mathrm{v}$ & $3900 \pm 110$ & $4155-3564^{(9)}$ & Gif-1934 & - & $3.0 \pm 1.0^{(9)}$ \\
\hline Praia de Mambucaba ${ }^{(3,4,5,6)}$ & $23^{\circ} 02,2^{\prime}$ & $44^{\circ} 33,2^{\prime}$ & $\mathrm{v}$ & $1840 \pm 90$ & $1581-1211^{(9)}$ & Bah-471 & - & $1.5 \pm 1.0^{(9)}$ \\
\hline Tarituba $^{(3,6)}$ & $23^{\circ} 02,9^{\prime}$ & $44^{\circ} 36,7^{\prime}$ & $\mathrm{V}$ & $975 \pm 80$ & $674-447^{(9)}$ & Bah-478 & - & $0.7 \pm 1.0^{(9)}$ \\
\hline Parati-Mirim $^{(3)}$ & $23^{\circ} 14,8^{\prime}$ & $44^{\circ} 37,6^{\prime}$ & $\mathrm{v}$ & $1490 \pm 80$ & $1221-884^{(9)}$ & Bah-482 & - & $1.0 \pm 1.0^{(9)}$ \\
\hline Mangaratiba $^{(3)}$ & $22^{\circ} 58,2^{\prime}$ & $44^{\circ} 02,8^{\prime}$ & $\mathrm{v}$ & $1630 \pm 65$ & $1296-1030^{(9)}$ & Bah-499 & - & $0.8 \pm 1.0^{(9)}$ \\
\hline Mosuaba $^{(3)}$ & $23^{\circ} 01,0^{\prime}$ & $44^{\circ} 13,3^{\prime}$ & $\mathrm{v}$ & $230 \pm 60$ & $0^{(9)}$ & Bah-483 & - & $0.5 \pm 1.0^{(9)}$ \\
\hline Ilha do Araújo ${ }^{(3)}$ & $23^{\circ} 09,2^{\prime}$ & $43^{\circ} 41,8^{\prime}$ & $\mathrm{v}$ & $2300 \pm 85$ & $2110-1698^{(9)}$ & Bah-470 & - & $1.4 \pm 1.0^{(9)}$ \\
\hline Coroa Grande $^{(3)}$ & $22^{\circ} 55,7^{\prime}$ & $43^{\circ} 50,6^{\prime}$ & $\mathrm{v}$ & $2595 \pm 90$ & $2494-1997^{(9)}$ & Bah-473 & - & $1.6 \pm 1.0^{(9)}$ \\
\hline Frade $^{(3)}$ & $22^{\circ} 58,7^{\prime}$ & $44^{\circ} 26,3^{\prime}$ & $\mathrm{v}$ & $2695 \pm 130$ & $2722-2081^{(9)}$ & Bah-465 & - & $1.5 \pm 1.0^{(9)}$ \\
\hline Mangaratiba $^{(3)}$ & $22^{\circ} 57,8^{\prime}$ & $44^{\circ} 02,6^{\prime}$ & $\mathrm{v}$ & $3255 \pm 100$ & $3320-2815^{(9)}$ & Bah-472 & - & $1.7 \pm 1.0^{(9)}$ \\
\hline Praia do $\mathrm{Meio}^{(5)}$ & $23^{\circ} 21,2^{\prime}$ & $44^{\circ} 43,3^{\prime}$ & $\mathrm{v}$ & $390 \pm 100$ & $0^{(9)}$ & Bah-488 & - & $0.4 \pm 1.0^{(9)}$ \\
\hline Praia Grande $^{(5)}$ & $23^{\circ} 09,2^{\prime}$ & $44^{\circ} 41,8^{\prime}$ & $\mathrm{v}$ & $500 \pm 80$ & $262-0^{(9)}$ & Bah-489 & - & $0.5 \pm 1.0^{(9)}$ \\
\hline Prainha, Arraial do Cabo ${ }^{(6.7)}$ & $22^{\circ} 57,6^{\prime}$ & $42^{\circ} 01,2^{\prime}$ & $\mathrm{v}$ & $2680 \pm 180$ & $2771-1924^{(9)}$ & Bah-1298 & - & $1.8 \pm 1.0^{(9)}$ \\
\hline Praia da Ferradura, Buzios ${ }^{(6,7)}$ & $22^{\circ} 46,2^{\prime}$ & $41^{\circ} 53,0^{\prime}$ & $\mathrm{v}$ & $3360 \pm 180$ & $3603-2761^{(9)}$ & Bah-1306 & - & $1.8 \pm 1.0^{(9)}$ \\
\hline Praia João Fernandes, Búzios ${ }^{(6,7)}$ & $22^{\circ} 44,3^{\prime}$ & $41^{\circ} 51,3^{\prime}$ & $\mathrm{v}$ & $3420 \pm 190$ & $3698-2781^{(9)}$ & Bah-1304 & - & $2.1 \pm 1.0^{(9)}$ \\
\hline Ponta do Retiro ${ }^{(6,7)}$ & $21^{\circ} 21,6^{\prime}$ & $40^{\circ} 57,6^{\prime}$ & $\mathrm{v}$ & $3620 \pm 150$ & $3895-3140^{(9)}$ & Bah-1008 & - & $3.0 \pm 1.0^{(9)}$ \\
\hline Cabo Frio - Búzios ${ }^{(8)}$ & $22^{\circ} 44^{\prime} 47^{\prime \prime}$ & $41^{\circ} 52^{\prime} 53^{\prime \prime}$ & $\mathrm{v}$ & $2810 \pm 95$ & $2745-2321$ & L-11A & 1.50 & $2.0 \pm 1.0^{(10)}$ \\
\hline Cabo Frio - Búzios ${ }^{(8)}$ & $22^{\circ} 44^{\prime} 51^{\prime \prime}$ & $41^{\circ} 52^{\prime} 49^{\prime \prime}$ & $\mathrm{v}$ & $3050 \pm 80$ & $3050-2683$ & BA-259845 & 1.43 & $1.9 \pm 1.0^{(10)}$ \\
\hline Cabo Frio - Búzios ${ }^{(8)}$ & $22^{\circ} 44^{\prime} 45^{\prime \prime}$ & $41^{\circ} 52^{\prime} 57^{\prime \prime}$ & $\mathrm{v}$ & $2760 \pm 70$ & $2686-2325$ & BA-259846 & 1.31 & $1.8 \pm 1.0^{(10)}$ \\
\hline Cabo Frio - Búzios $^{(8)}$ & $22^{\circ} 44^{\prime} 48^{\prime \prime}$ & $41^{\circ} 52^{\prime} 51^{\prime \prime}$ & $\mathrm{v}$ & $2890 \pm 60$ & $2780-2453$ & BA-259847 & 1.81 & $2.3 \pm 1.0^{(10)}$ \\
\hline Cabo Frio - Búzios ${ }^{(8)}$ & $22^{\circ} 44^{\prime} 43^{\prime \prime}$ & $41^{\circ} 52^{\prime} 50^{\prime \prime}$ & $\mathrm{v}$ & $2760 \pm 70$ & $2686-2325$ & BA-259848 & 1.38 & $1.9 \pm 1.0^{(10)}$ \\
\hline Cabo Frio - Búzios ${ }^{(8)}$ & $22^{\circ} 52^{\prime} 47^{\prime \prime}$ & $42^{\circ} 01^{\prime} 08^{\prime \prime}$ & $\mathrm{b}$ & $3820 \pm 70$ & $3960-3581$ & BA-259849 & 2.0 & $2.5 \pm 1.0^{(10)}$ \\
\hline Cabo Frio - Búzios ${ }^{(8)}$ & $22^{\circ} 52^{\prime} 41^{\prime \prime}$ & $42^{\circ} 01^{\prime} 03^{\prime \prime}$ & $\mathrm{v}$ & $4400 \pm 60$ & $4771-4409$ & BA-259850 & 2.5 & $3.0 \pm 1.0^{(10)}$ \\
\hline Cabo Frio - Búzios $^{(8)}$ & $22^{\circ} 52^{\prime} 40^{\prime \prime}$ & $42^{\circ} 01^{\prime} 09 ”$ & $\mathrm{v}$ & $2350 \pm 70$ & $2153-1798$ & BA-262078 & 1.37 & $1.9 \pm 1.0^{(10)}$ \\
\hline Cabo Frio - Búzios $^{(8)}$ & $22^{\circ} 47^{\prime} 19^{\prime \prime}$ & $41^{\circ} 55^{\prime} 57^{\prime \prime}$ & $\mathrm{v}$ & $1410 \pm 40$ & $1040-890$ & BA-270651 & 0.85 & $1.4 \pm 1.0^{(10)}$ \\
\hline Cabo Frio - Búzios ${ }^{(8)}$ & $22^{\circ} 47^{\prime} 19^{\prime \prime}$ & $41^{\circ} 55^{\prime} 57^{\prime \prime}$ & $\mathrm{v}$ & $1540 \pm 40$ & $1180-1000$ & BA-270650 & 0.90 & $1.4 \pm 1.0^{(10)}$ \\
\hline
\end{tabular}

Sources: (1) Laborel 1969, (2) Delibrias and Laborel 1969, (3) Martin and Suguio 1978, (4) Martin et al. 1979, (5) Martin et al. 1979/80, (6) Martin and Suguio 1989, (7) Martin et al. 1997, (8) Castro et al. 2014, (9) after Angulo et al. 2006, (10) this paper.

Notes: (SL) South latitude, (WL) West longitude, (N) sample nature, $\left({ }^{14} \mathrm{C}\right.$ a $\left.\mathrm{BP}\right)$ radiocarbon years before present, (cal a BP) calibrated years before present, (R) laboratory reference, (H) height, (PSL) paleo-sea level (v) vermetid, (b) barnacle Tetraclita stalactifera. (Gif) Centre des Faibles Radioactivités, C.N.R.S., Gif-sur-Yvette, France, (Bah) Laboratório de Física Nuclear Aplicada, Instituto de Geociências e Instituto de Física, Universidade Federal da Bahia, (BA) Beta Analytic, Miami, Florida, USA. (L) Lagecost - Laboratório de Geologia Costeira, Sedimentologia e Meio Ambiente, Departamento de Geologia e Paleontologia do Museu Nacional, Universidade Federal do Rio de Janeiro.

as to which listed samples the points in the curve correspond to.

(5) We note a divergence between the results in the paper under discussion and those from Castro et al. (2012), in regard to the ages attributed to two samples of shells from beachrocks: $7910-7690{ }^{14} \mathrm{C}$ cal a BP in Castro et al. (2014) and 12,910-12,690 ${ }^{14} \mathrm{C}$ cal a BP in Castro et al. (2012) (Beta Analytic 248722), and $3130-2860{ }^{14} \mathrm{C}$ cal a BP at Castro et al. (2014) and $13,130-12,860{ }^{14} \mathrm{C}$ cal a BP at Castro et al. (2012) (Beta Analytic 248723). These inconsistencies are not justified by Castro et al. (2014). 


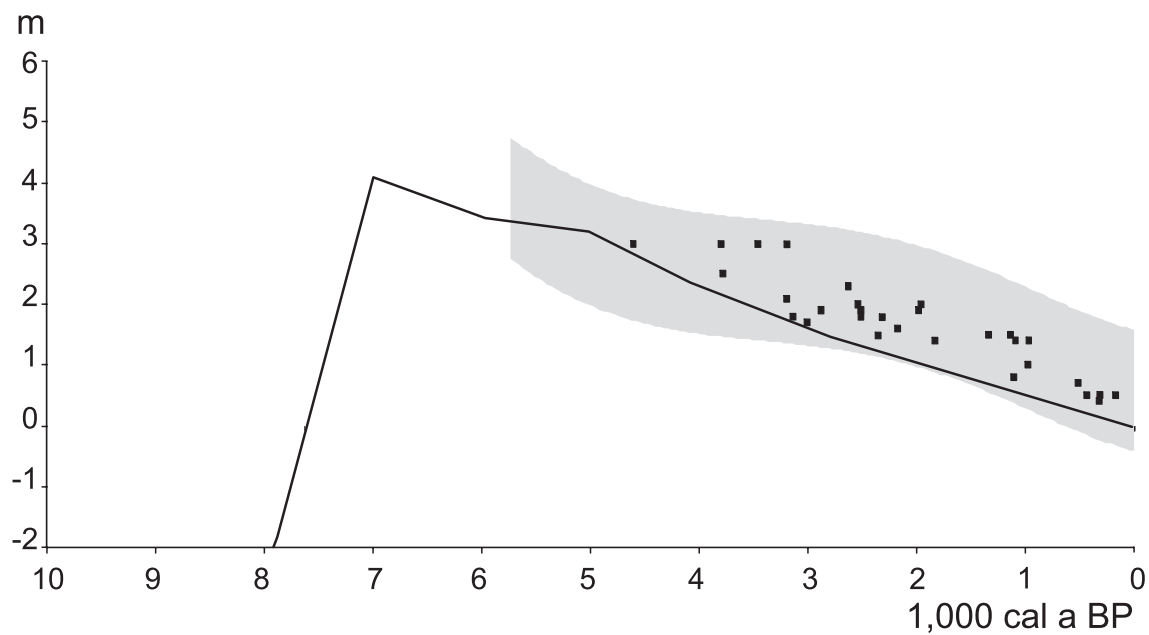

Figure 1 - Eustatic sea-level curve (Milne et al. 2005, solid line), sea-level envelope (Angulo et al. 2006, gray area) and paleo-sea level reconstructions from vermetids and barnacles (black squares) for the coast of Rio de Janeiro.

Considering the indicators presented by Castro et al. (2014), it is possible to suggest the following interpretations:

(a) Vermetids and Tetraclita stalactifera

Vermetids and Tetraclita stalactifera live next to the low water level (see e.g. van Andel and Laborel 1964, Laborel 1979, 1986), or about $0.5 \mathrm{~m}$ below mean-sea level in Cabo Frio, where the tide range is around $1 \mathrm{~m}$. Therefore, to infer a paleo-sea level from remains of vermetids or Tetraclita stalactifera it is necessary to add 0.5 $\mathrm{m}$ (the difference between mean and low tide levels) to their altitude. However, the altitude of the living zone of vermetids also depends on wave exposure (Laborel 1969, 1986) and morphology of rocky coast (Delibrias and Laborel 1969). This is why it is necessary to compare the old remains with living organisms at similar tidal and wave exposure conditions, taking into account that those conditions might have changed since the organisms died (Angulo et al. 1999). It is also necessary to assess to which part of the vermetid reef (it can span more than $1 \mathrm{~m}$ vertically) the remains correspond to (Angulo et al. 1999). Therefore, the margin of error could range between $\pm 0.1 \mathrm{~m}$ to 1.0 m (Laborel 1969, 1986, Angulo et al. 1999). The paleo-sea level reconstructions from vermetids and Tetraclita stalactifera from Cabo Frio, considering an error margin of $\pm 1.0 \mathrm{~m}$, fit with reconstructions published elsewhere, such as the curve presented by Angulo et al. (2006) and the models for eustatic sea-level variations proposed by Milne et al. (2005) for this same region (Fig. 1 and Table I).

(b) Shells from beachrocks

Shells older than 7.000 years BP were collected from beachrocks (Table II). To infer paleo-sea levels from this indicator it is necessary to consider that shells can be older than the beachrock and therefore provide only a maximum age. Castro et al. (2014) did not consider this premise. This common misunderstanding led the authors to suggest that sea level was $4.5 \mathrm{~m}$ below the current one between 11,000 and 12,000 years BP, and in addition to claim that this is the first identified negative sealevel record during Late Pleistocene and Early Holocene transition on the Brazilian coast. This interpretation does not fit with the wide accepted global sea-level curves (e.g. see Pirazzoli 1996), which indicate that at that time, sea-level was still ascending at full throttle and was tens of meters (30 to $90 \mathrm{~m}$ ) lower than the present one. Therefore, it is possible to deduce that the dated shells contained 
in the beachrock are thousands of years older than the sedimentary deposit itself. This is a common issue and has been verified on Holocene barriers everywhere, including Brazil where vegetal debris are up to 5 thousand years older than the sedimentary deposit (Angulo et al. 2008).

TABLE II

Dated beachrock shells and cement from the coast of Rio de Janeiro.

\begin{tabular}{|c|c|c|c|c|c|c|c|}
\hline Place & SL & WL & $\mathrm{N}$ & ${ }^{14} \mathrm{C}$ a BP & cal a BP & $\mathrm{R}$ & $\mathrm{H}(\mathrm{m})$ \\
\hline Jaconé beach $^{(1)}$ & $22^{\circ} 55^{\prime} 58^{\prime \prime}$ & $42^{\circ} 34^{\prime} 04^{\prime \prime}$ & $\mathrm{c}$ & $7410 \pm 30$ & $6008-5786$ & CAIS & 0.0 \\
\hline \multirow[t]{2}{*}{ Jaconé beach $^{(1)}$} & $22^{\circ} 55^{\prime} 58^{\prime \prime}$ & $42^{\circ} 34^{\prime} 04^{\prime \prime}$ & b-s-f & $9190 \pm 30$ & $8198-7827$ & CAIS & $<0.0^{(2)}$ \\
\hline & & & & & & & $-0.5^{(1)}$ \\
\hline Praia do Farol, Ilha do Cabo Frio ${ }^{(2)}$ & $22^{\circ} 57^{\prime} 59^{\prime \prime}$ & $42^{\circ} 01^{\prime} 41^{\prime \prime}$ & $\mathrm{s}$ & $10460 \pm 70$ & $11,940-11,240$ & BA-248721 & -4.5 \\
\hline Praia do Farol, Ilha do Cabo Frio ${ }^{(2)}$ & $22^{\circ} 01^{\prime} 41^{\prime \prime}$ & $42^{\circ} 01^{\prime} 41^{\prime \prime}$ & $\mathrm{s}$ & $10250 \pm 50$ & $11,337-11,149$ & BA-243863 & -3.0 \\
\hline \multirow[t]{2}{*}{ Praia do Farol, Ilha do Cabo Frio ${ }^{(2)}$} & $22^{\circ} 01^{\prime} 42^{\prime \prime}$ & $42^{\circ} 00^{\prime} 42^{\prime \prime}$ & $\mathrm{s}$ & $11,090 \pm 60^{(2)}$ & $12,910-12,690^{(2)}$ & BA-248722 & 0.0 \\
\hline & & & & $7090 \pm 60^{(3)}$ & $7910-7690^{(3)}$ & & \\
\hline \multirow[t]{2}{*}{ Praia do Farol, Ilha do Cabo Frio ${ }^{(2)}$} & $22^{\circ} 01^{\prime} 42^{\prime \prime}$ & $42^{\circ} 011^{\prime} 42^{\prime \prime}$ & $\mathrm{s}$ & $13,130 \pm 80^{(2)}$ & $13,130-12,860^{(2)}$ & BA-248723 & 1.5 \\
\hline & & & & $3210 \pm 80^{(3)}$ & $3130-2860^{(3)}$ & & \\
\hline $\mathrm{Cabo} \mathrm{Frio}^{(3)}$ & $22^{\circ} 45^{\prime} 49^{\prime \prime}$ & $41^{\circ} 57^{\prime} 27^{\prime \prime}$ & $\mathrm{s}$ & $5460 \pm 40$ & $6330-6190$ & BA-310447 & 0.50 \\
\hline $\mathrm{Cabo} \mathrm{Frio}^{(3)}$ & $22^{\circ} 52^{\prime} 24^{\prime \prime}$ & $42^{\circ} 20^{\prime} 36^{\prime \prime}$ & $\mathrm{s}$ & $2500 \pm 30$ & $2270-2090$ & BA-332410 & 0.50 \\
\hline $\mathrm{Cabo} \mathrm{Frio}^{(3)}$ & $22^{\circ} 44^{\prime} 52^{\prime \prime}$ & $41^{\circ} 52^{\prime} 57^{\prime \prime}$ & $\mathrm{s}$ & $5490 \pm 30$ & $5910-5830$ & BA-332411 & - \\
\hline Cabo Frio $^{(3)}$ & $22^{\circ} 44^{\prime} 49^{\prime \prime}$ & $41^{\circ} 52^{\prime} 48^{\prime \prime}$ & $\mathrm{s}$ & $5000 \pm 30$ & $5430-5280$ & BA-332412 & - \\
\hline $\mathrm{Cabo} \mathrm{Frio}^{(3)}$ & $22^{\circ} 44^{\prime} 41^{\prime \prime}$ & $41^{\circ} 55^{\prime} 56^{\prime \prime}$ & $\mathrm{s}$ & $5780 \pm 70$ & $5997-6335$ & BA-262079 & 0.94 \\
\hline
\end{tabular}

Sources: (1) Mansur et al. 2011, (2) Castro et al. 2012, (3) Castro et al. 2014. Notes: Notes: (SL) South latitude, (WL) West longitude, (N) sample nature, $\left({ }^{14} \mathrm{C}\right.$ a BP) radiocarbon years before present, (cal a BP) calibrated years before present, (R) laboratory reference, (H) height, (c) cement, (b) bivalve, (s) mollusc shell, (f) fragments, (CAIS) Center of Applied Isotopic Studies of Georgia University, Athens, USA, (BA) Beta Analytic, Miami, Florida, USA.

To use the beachrock, or any coastal sedimentary deposit, as an indication of paleo-sea levels demands knowledge of its sedimentary facies association. No information about the beachrock facies is provided by Castro et al. (2014). The authors only inform that the sedimentological and stratigraphic characteristics of the beach environment, which include a tabular morphology with smooth dips below $>3^{\circ}$ and a micro-tidal regime with variations of $<1.0 \mathrm{~m}$ on the coast of the state of Rio de Janeiro, confer accuracy to these rocks as indicators of the mean sea-level. Consequently, they infer that all altitude samples correspond to former mean-sea level. It is well known that beachrocks have different origins and can be formed at several altitudes (see e.g. Stoddart and Cann 1965, Hopley 1986, Turner 2005, Vousdoukas et al. 2007). One of the samples used by Castro et al. (2014) to build their curve corresponds to mollusk shell fragments from
Jaconé beachrock described and dated by Mansur et al. (2011). After analyzing the beachrock facies, Mansur et al. (2011) concluded that the dated shells fragments were deposited at the lower part of the beach face at a time when sea-level was a little lower than the present one. Hence, it can be suggested that sea-level was a little lower $(0.5 \mathrm{~m}$, according Castro et al. 2014) than the present one between 8198-7827 cal a BP (age of shell fragments) and 6008-5786 cal a BP (age of beachrock cement, Mansur et al. 2011, Table II), which again fits with the eustatic sea-level curve produced by Milne et al. (2005).

We argue that the dates presented by Castro et al. (2014), when correctly interpreted, are compatible with the eustatic sea-level curve proposed by Milne et al. (2005) for the coast of Rio de Janeiro, with the sea-level envelope proposed by Angulo et al. (2006) for the Brazilian coast between Pernambuco 
and Santa Catarina and with former data published from the coast of Rio de Janeiro. In summary, it can be stated that: (a) the paleo-sea levels inferred by vermetid remains show that sea-level has fallen over the past $4400 \mathrm{cal}$ a BP; at least (b) the paleosea level inferred by the beachrock facies and dated shells of Jaconé shows that sea-level was near the present elevation between 8198 and 5786 cal a BP; and (c) several shells from other beachrocks were deposited probably thousands of years after the specimens died and consequently do not allow precise reconstructions of paleo-sea levels.

\section{REFERENCES}

ANGULO RJ, GIANNINI PCF, SUGUIO K AND PESSENDA LCR. 1999. The relative sea-level changes in the last 5500 years southern Brazil (Laguna-Imbituba region, Santa Catarina State) based on vermetid 14C ages. Mar Geol 159: 327-339.

ANGULO RJ, LESSA GC AND SOUZA MC. 2006. A critical review of Mid- to Late Holocene sea-level fluctuations on the eastern Brazilian coastline. Quat Scien Rev 25: 486506.

ANGULO RJ, SOUZA MC, ASSINE ML, PESSENDA LCR AND DISARÓ ST. 2008. Chronostratigraphy and radiocarbon age inversion in the Holocene regressive barrier of Paraná, southern Brazil. Mar Geol 252(3-4): 111-119.

BRANNER JC. 1902. Geology of northeast coast of Brazil. Bull Geol Soc Ame 13: 41-98.

BRANNER JC. 1904. The stone reef of Brazil, their geological and geographical relations, with a chapter on the coral reefs. Bull Mus Comp Zool Harvard Coll v. 44, Geological Series v. 7. Cambridge, Massachuset, USA, 285 p. 99 plates.

CASTRO JWA, SUGUIO K, CUNHA AM DA, GUEDES E, TÂMEGA FT DE S AND RODRIGUEZ RR. 2012. Rochas de praia (beachrocks) da ilha de Cabo Frio, Arraial do Cabo: registro geológico ímpar da transição Pleistoceno-Holoceno no estado do Rio de Janeiro. Anu Inst Geoc - UFRJ 35(1): 236-241.

CASTRO JWA, SUGUIO K, SEOANE JCS, CUNHA AM DA AND DIAS FF. 2014. Sea-level fluctuations and costal evolution in the state of Rio de Janeiro southeastern Brazil. An Acad Bras Cienc 86: 671-683.

DELIBRIAS G AND LABOREL J. 1969. Recent variations of the sea level along the Brazilian coast. Quaternaria 14: 45-49.

HARTT CF. 1870. Geology and physical geography of Brazil. Fields, Osgood \& Co., Boston, 620 p.
HOPLEY D. 1986. Beachrock as a sea-level indicator. In: Van de Plassche O (Ed), Sea-level Research: a Manual for the Collection and Evaluation of Data. Geo Books, Norwich, p. $157-173$.

LABOREL J. 1969. Les pouplements de madréporaires des côtes tropicales du Brésil. Annales de l'Universtité D'Abidjan, Serie E-II Fascicule 3, Ecologie, 261 p.

LABOREL J. 1979. Fixed marine organisms as biological indicator for the study of recent sea level and climatic variations along the Brazilian tropical coast. In: Suguio K et al. (Eds), Proceedings of the International Symposium on Coastal Evolution in the Quaternary, p. 193-211.

LABOREL J. 1986. Vermetid gastropods as sea-level indicators. In: Van de Plassche O (Ed), Sea-level Research: a Manual for the Collection and Evaluation of Data. Geo Books, Norwich, p. 281-310.

MAIA MCAC, MARTIN L, FLEXOR JM AND AZEVEDO AEG. 1984. Evolução holocênica da planície costeira de Jacarepaguá (RJ). In: Anais do $33^{\circ}$ Congresso Brasileiro de Geologia 1: 105-118.

MANSUR KL, RAMOS RRC, GODOY JM DE O AND NASCIMENTO VMR DO. 2011. Beachrocck de Jaconé, Maricá e Saquarema - RJ: importância para a história da ciência e para o conhecimento geológico. Rev Bras Geoc 41(2): 290-303.

MARTIN L, DOMINGUEZ JML AND BITTENCOURT ACSP. 2003. Fluctuating Holocene sea levels is eastern and southeastern Brazil: evidence from a multiple fossil and geometric indicators. J Coast Res 19: 101-124.

MARTIN L, DOMINGUEZ JML, SUGUIO K, BITTENCOURT ACSP AND FLEXOR JM. 1983. Schéma de la sédimentation quaternaire sur la partie centrale du littoral brésilien. Cahiers O.R.S.T.O.M., Série Géologie 13(1): 59-81.

MARTIN L, MÖRNER NA, FLEXOR JM AND SUGUIO K. 1982. Reconstrução de antigos níveis marinhos do quaternário. Publicação Especial da Comissão TécnicoCientífica do Quaternário, Soc Bras Geol, 154 p.

MARTIN L AND SUGUIO K. 1978. Excursion route along the coastline between the town of Cananéia (state of São Paulo) and Guaratiba outlet (state of Rio de Janeiro). In: International Symposium on Coastal Evolution, Special Publication 2: 1-98.

MARTIN L AND SUGUIO K. 1989. Excursion route along the Brazilian coast between Santos (SP) and Campos (RJ) (North of State of Rio de Janeiro). In: International Symposium on Global Changes in South America during the Quaternary, Special Publication 2: 1-136.

MARTIN L, SUGUIO K, DOMINGUEZ JML AND FLEXOR JM. 1997. Geologia do Quaternário costeiro do litoral norte do Rio de Janeiro e do Espírito Santo. CPRM, Belo Horizonte, 112 p., 2 maps.

MARTIN L, SUGUIO K AND FLEXOR JM. 1979. Le Quaternaire marin du littoral brésilien entre Cananéia 
(SP) et Barra de Guaratiba (RJ). In: Suguio K et al. (Eds), Proceedings of the International Symposium on Coastal Evolution in the Quaternary, p. 296-331.

MARTIN L, SUGUIO K, FLEXOR JM, BITTENCOURT ACSP AND VILAS-BOAS GS. 1979/1980. Le quaternaire marin brésilien (littoral pauliste, sud fluminense et bahianais). Cahiers O.R.S.T.O.M., Série Géologie 11: 95124.

MARTIN L, SUGUIO K, FLEXOR JM, DOMINGUEZ JML AND AZEVEDO AEG DE. 1984. Evolução da planície costeira do rio Paraíba do Sul (RJ) durante o Quaternário: Influência das flutuações do nível do mar. In: Anais do $33^{\circ}$ Congresso Brasileiro de Geologia 1: 84-97.

MARTIN L, SUGUIO K, FLEXOR JM, DOMINGUEZ JML AND BITTENCOURT ACSP. 1996. Quaternary sea-level history and variation in dynamics along the central Brazil Coast: consequences on coastal plain construction. An Acad Bras Cienc 68: 303-354.
MILNE GA, LONG AJ AND BASSETT E. 2005. Modeling Holocene relative sea-level observations from the Caribbean and South America. Quat Scie Rev 24: 1183-1202.

PIRAZZOLI PA. 1996. Sea-level changes: The last 20000 years. J Wiley \& Sons, $211 \mathrm{p}$.

STODDART DR AND CANN JR. 1965. Nature and origin of beach rock. J Sed Petrol 35(1): 243-247.

TURNER RJ. 2005. Beachrock. In: Schwartz ML (Ed), Encyclopedia of coastal science. Kluwer Academic Publishers, The Netherlands, p. 183-186.

VAN ANDEL TH AND LABOREL J. 1964. Recent high relative sea level stand near Recife, Brazil. Science 145: 580-581.

VAN DE PLASSCHE O (Ed). 1986. Sea-level Research: a Manual for the Collection and Evaluation of Data. Geo Books, Norwich, 618 p.

VOUSDOUKAS MI, VELEGRAKIS AF AND PLOMARITIS TA. 2007. Beachrock occurrence, characteristics, formation mechanisms and impacts. Earth-Science Rev 85: 23-46. 